\title{
Front Matter: Volume 10090
}

, "Front Matter: Volume 10090," Proc. SPIE 10090, Laser Resonators, Microresonators, and Beam Control XIX, 1009001 (30 March 2017); doi: $10.1117 / 12.2276094$

SPIE. Event: SPIE LASE, 2017, San Francisco, California, United States 


\title{
PROCEEDINGS OF SPIE
}

\section{Laser Resonators, Microresonators, and Beam Control XIX}

\author{
Alexis V. Kudryashov \\ Alan H. Paxton \\ Vladimir S. Ilchenko \\ Editors
}

30 January-2 February 2017

San Francisco, California, United States

Sponsored and Published by

SPIE 
The papers in this volume were part of the technical conference cited on the cover and title page. Papers were selected and subject to review by the editors and conference program committee. Some conference presentations may not be available for publication. Additional papers and presentation recordings may be available online in the SPIE Digital Library at SPIEDigitallibrary.org.

The papers reflect the work and thoughts of the authors and are published herein as submitted. The publisher is not responsible for the validity of the information or for any outcomes resulting from reliance thereon.

Please use the following format to cite material from these proceedings:

Author(s), "Title of Paper," in Laser Resonators, Microresonators, and Beam Control XIX, edited by Alexis V. Kudryashov, Alan H. Paxton, Vladimir S. Ilchenko, Proceedings of SPIE Vol. 10090 (SPIE, Bellingham, WA, 2017) Seven-digit Article CID Number.

ISSN: 0277-786X

ISSN: 1996-756X (electronic)

ISBN: 9781510606210

ISBN: 9781510606227 (electronic)

Published by

SPIE

P.O. Box 10, Bellingham, Washington 98227-0010 USA

Telephone +1 3606763290 (Pacific Time) · Fax +1 3606471445

SPIE.org

Copyright @ 2017, Society of Photo-Optical Instrumentation Engineers.

Copying of material in this book for internal or personal use, or for the internal or personal use of specific clients, beyond the fair use provisions granted by the U.S. Copyright Law is authorized by SPIE subject to payment of copying fees. The Transactional Reporting Service base fee for this volume is $\$ 18.00$ per article (or portion thereof), which should be paid directly to the Copyright Clearance Center (CCC), 222 Rosewood Drive, Danvers, MA 01923. Payment may also be made electronically through CCC Online at copyright.com. Other copying for republication, resale, advertising or promotion, or any form of systematic or multiple reproduction of any material in this book is prohibited except with permission in writing from the publisher. The CCC fee code is 0277-786X/17/\$18.00.

Printed in the United States of America.

Publication of record for individual papers is online in the SPIE Digital Library.

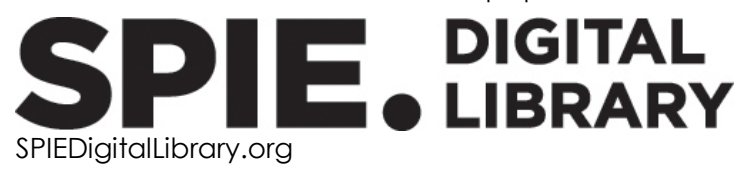

Paper Numbering: Proceedings of SPIE follow an e-First publication model. A unique citation identifier (CID) number is assigned to each article at the time of publication. Utilization of CIDs allows articles to be fully citable as soon as they are published online, and connects the same identifier to all online and print versions of the publication. SPIE uses a seven-digit CID article numbering system structured as follows:

- The first five digits correspond to the SPIE volume number.

- The last two digits indicate publication order within the volume using a Base 36 numbering system employing both numerals and letters. These two-number sets start with 00, 01, 02, 03, 04, 05, 06, 07, 08, 09, 0A, OB ... OZ, followed by 10-1Z, 20-2Z, etc. The CID Number appears on each page of the manuscript. 


\title{
Contents
}

\author{
vii Authors \\ ix Conference Committee
}

MICRORESONATORS: NOVEL TOPOLOGIES AND DEVICES I

1009002 Q-factor enhancement of integrated lithium-niobate-on-insulator ridge waveguide whispering-gallery-mode resonators by surface polishing [10090-1]

1009006 Cavity designs for GHz frequency combs (Invited Paper) [10090-5]

MICRORESONATORS IN LASERS AND RF PHOTONICS

1009008 Whispering gallery mode stabilization of quantum cascade lasers for infrared sensing and spectroscopy (Invited Paper) [10090-7]

FREQUENCY COMBS WITH OPTICAL RESONATORS I: JOINT SESSION WITH CONFERENCES 10088 AND 10090

$10090 \mathrm{OE}$ Kerr combs from normal and anomalous dispersion silicon nitride microresonators (Invited Paper) [10090-13]

10090 OF Effect of Raman scattering and mode coupling in Kerr comb generation in a silica whispering gallery mode microcavity (Invited Paper) [10090-14]

FREQUENCY COMBS WITH OPTICAL RESONATORS II: JOINT SESSION WITH CONFERENCES 10088 AND 10090

10090 OG Chip-scale frequency comb generators for high-speed communications and optical metrology (Invited Paper) [10090-15]

MICRORESONATORS: NONLINEAR EFFECTS, OPTOMECHANICS, AND SENSING I

10090 OP Advances in microwave generation using Kerr optical frequency combs (Invited Paper) [10090-25]

BEAM SHAPING I: JOINT SESSION WITH CONFERENCES 10090 AND 10097

10090 OT High-resolution high-reflective LCOS spatial light modulator for beam manipulation beyond visible spectrum [10090-29] 
10090 OU Super narrow beam shaping system for remote power supply at long atmospheric paths [10090-30]

10090 OV Generation of an ultra-flexible focused top-hat beam profile with aspheres [10090-31]

BEAM SHAPING II: JOINT SESSION WITH CONFERENCES 10090 AND 10097

10090 OY Numerical design of gradient-index beam shapers (Invited Paper) [10090-34]

$100900 Z$ Multiplexing of spatial modes in the mid-IR region [10090-35]

1009010 Integrated optical design for highly dynamic laser beam shaping with membrane deformable mirrors [10090-36]

1009011 Mode profiles and Airy distributions of Fabry-Pérot resonators with frequency-dependent mirror reflectivity [10090-37]

MICRORESONATORS: NONLINEAR EFFECTS, OPTOMECHANICS, AND SENSING II

1009012 Integrated asymmetric whispering gallery mode resonator microcavity optomechanics [10090-38]

1009014 The linewidth of distributed feedback resonators: the combined effect of thermally induced chirp and gain narrowing [10090-40]

1009016 High-resolution temperature sensor through measuring the frequency shift of singlefrequency Erbium-doped fiber ring laser [10090-42]

MICRORESONATORS: NONLINEAR EFFECTS, OPTOMECHANICS, AND SENSING III

1009017 Impact of zirconium dopants on the lasing efficiency of Raman microcavity laser [10090-43]

MICRORESONATORS: NONLINEAR EFFECTS, OPTOMECHANICS, AND SENSING IV

10090 1C Enhanced sensitivity in PT-symmetric coupled resonators [10090-47]

10090 ID Coupled mode analysis of micro-disk resonators with an asymmetric-index-profile coupling region [10090-48]

10090 IF New spherical optical cavities with non-degenerated whispering gallery modes [10090-49]

$100901 G$ Automatic channel-switched intracavity-absorption acetylene sensor based on modecompetition via Sagnac loop filter [10090-51] 
1009011 Parameter optimization of a vectorial optical field generator for precise spatial polarization control [10090-53]

$100901 \mathrm{~J}$ The investigation of iodine cell temperature control in frequency stabilized Nd:YAG laser system [10090-54]

$100901 \mathrm{~K}$ The use of modified hill-climbing algorithm for laser beam focusing through the turbid medium [10090-55]

10090 1L Photonic crystal microchip laser [10090-56]

10090 1M Unstable resonators for high power diode pumped alkali lasers [10090-57]

$100901 \mathrm{~N}$ Control of pulse format in high energy per pulse all-fiber erbium/ytterbium laser systems [10090-58]

\section{BEAM DIAGNOSTICS AND SHAPING}

1009010 Analysis of the emission characteristics of diode lasers by their wavefront structure [10090-59]

10090 1Q Self-calibrating, real-time M-square measurement system [10090-61]

10090 IR Conical refraction of a high-M $\mathbf{M}^{2}$ laser beam [10090-62]

10090 is Beam shaping by means of different wavefront correctors [10090-63]

\section{POSTER SESSION}

$100901 \mathrm{X}$ Optical and magnetic characterization of transition metal ion doped ZnO microspheres synthesized via laser ablation in air [10090-68]

$100901 Y$ Laser simulation applying Fox-Li iteration: investigation of reason for non-convergence [10090-69] 
Proc. of SPIE Vol. $100901009001-6$

Downloaded From: https://www.spiedigitallibrary.org/conference-proceedings-of-spie on 26 Apr 2023 Terms of Use: https://www.spiedigitallibrary.org/terms-of-use 


\title{
Authors
}

Numbers in the index correspond to the last two digits of the seven-digit citation identifier (CID) article numbering system used in Proceedings of SPIE. The first five digits reflect the volume number. Base 36 numbering is employed for the last two digits and indicates the order of articles within the volume. Numbers start with 00, 01, 02, 03, 04, 05, 06, 07, 08, 09, OA, OB...0Z, followed by 10-1Z, 20-2Z, etc.

\author{
Alexandrov, Alexander, 15 \\ Almuneau, G., 1D \\ Anitha Sukkurji, Parvathy, $1 \mathrm{X}$ \\ Arissian, Ladan, 06 \\ Arlotti, C., 1D \\ Armani, Andrea M., 12, 17 \\ Babanin, E. A., OU \\ Barry, L. P., OG \\ Bernhardi, Edward H., 14 \\ Block, Matthew K., IN \\ Borri, Simone, 08 \\ Brasch, V., OG \\ Breunig, Ingo, 02 \\ Buranasiri, P., $1 \mathrm{~J}$ \\ Buse, Karsten, 02 \\ Calil Kores, Cristine, 11, 14 \\ Calvez, S., 1D \\ Chembo, Yanne K., OP \\ Chen, Jian, 11 \\ Chimot, N., OG \\ Choi, Hyungwoo, 17 \\ Christodoulides, D. N., 1C \\ De Natale, Paolo, 08 \\ Deffenbaugh, James, $1 \mathrm{~N}$ \\ Diels, Jean-Claude, 06 \\ Dijkstra, Meindert, 14 \\ Duan, Liangcheng, 16, $1 G$ \\ Dudley, Angela, $\mathrm{OZ}$ \\ Eichentopf, Inga-Maria, 10 \\ Eliyahu, Danny, 08 \\ Fedorova, K. A., 1R \\ Fitzpatrick, Zak G., $1 \mathrm{~N}$ \\ Forbes, Andrew, $\mathrm{OZ}$ \\ Freude, W., OG \\ Fu, Shijie, 16 \\ Fuchs, U., OV \\ Fujii, Shun, OF \\ Fujiwara, Yuki, IX \\ Gailele, Lucas, $\mathrm{OZ}$ \\ Gailevicius, D., $1 \mathrm{~L}$ \\ Galaktionov, llya, $1 \mathrm{~K}$ \\ Garcia-Gracia, H., 1C \\ Gauthier-Lafaye, O., 1D \\ Gavrielides, Athanasios, 1M \\ Geskus, Dimitri, 11, 14 \\ Haas, Gil, 1Q \\ Hassan, A. U., 1C \\ Hawks, Michael R., 1M \\ Hayenga, W. E., $1 \mathrm{C}$
}

\author{
Henry, Leanne J., IN \\ Higashihata, Mitsuhiro, $1 \mathrm{X}$ \\ Hodaei, H., 1C \\ Hori, Atsuhiro, OF \\ Hudnut, Alexa W., 12 \\ Ilchenko, Vladimir, 08 \\ Insero, Giacomo, 08 \\ Ismail, Nur, 11, 14 \\ Jain, Ravinder, $1 \mathrm{~N}$ \\ Kapranov, V. V., OU \\ Karpov, M., OG \\ Kato, Takumi, OF \\ Kemal, J. N., OG \\ Kerbstadt, Fabian, OT \\ Khajavikhan, M., 1C \\ Kippenberg, T. J., OG \\ Kishi, Tetsuo, $1 \mathrm{~F}$ \\ Klopfer, Michael, $1 \mathrm{~N}$ \\ Koliadenko, $V_{\text {., }} 1 \mathrm{~L}$ \\ Kong, Lingjiang, 11 \\ Koos, C., OG \\ Kordts, A., OG \\ Kudryashov, Alexis, 1K, is \\ Kumagai, Tsutaru, $1 \mathrm{~F}$ \\ Kunkel, W. Minster, OY \\ Lazarev, Grigory, OT \\ Leger, James R., OY \\ Lelarge, F., OG \\ Limsuwan, P., $1 \mathrm{~J}$ \\ Loosen, Peter, 10 \\ Loper, Robert D., IM \\ Losev, S. N., IR \\ LU, Ying, $1 G$ \\ Luberek, Jarek, OT \\ Lylova, Anna, is \\ Maleki, Lute, 08 \\ Marin, P., OG \\ Martinez, A., OG \\ Matsak, I. S., OU \\ Matsko, Andrey, 08 \\ Maweza, Loyiso, $0 z$ \\ Möhl, A., OV \\ Mylnikov, V. YU., IR \\ Nakamura, Daisuke, $1 \mathrm{X}$ \\ Ndagano, Bienvenu, $\mathrm{OZ}$ \\ Nikitin, Alexander, $1 \mathrm{~K}$ \\ Palma, Giuseppe, IF \\ Panapakkam, V., OG \\ Paxton, Alan H., IY
}


Peckus, M., $1 \mathrm{~L}$

Perram, Glen P., $1 \mathrm{M}$

Pfeifle, J., OG

Pollnau, Markus, 11, 14

Potirak, P., $1 \mathrm{~J}$

Prudenzano, Francesco, $1 \mathrm{~F}$

Purlys, V., 1L

Pütsch, Oliver, 10

Qi, Minghao, OE

Rafailov, E. U., IR

Ramdane, A., OG

Ranusawud, M., $1 \mathrm{~J}$

Rao, M. S. Ramachandra, $1 X$

Reufer, Martin, 10

Rosales-Guzman, Carmelo, $\mathrm{OZ}$

Rui, Guanghao, 11

Saleh, Khaldoun, OP

Samarkin, Vadim, is

Santambrogio, G., 08

Savchenkov, Anatoliy, 08

Scaggs, Michael, 1Q

Schlie, L. A. (Vern), IM

Sergeev, E. S., OU

Sheldakova, Julia, 1K, $1 \mathrm{~S}$

Sheng, Quan, 16, 1G

Shi, Wei, 16, $1 G$

Siciliani de Cumis, Mario, 08

Sokolovskii, G. S., 1 R

Soltani, Soheil, 12

Staliunas, K., $1 \mathrm{~L}$

Stollenwerk, Jochen, 10

Suhareva, N. A., OU

Suzuki, Ryo, OF

Tanabe, Takasumi, OF

Taranenko, V., $1 \mathrm{~L}$

Trocha, P., OG

Tugaenko, V. YU., OU

Urioste, Michael T., 1N

Vasa, Nilesh Jayantilal, $1 \mathrm{X}$

Vujicic, V., OG

Watts, R. T., OG

Weimann, C., OG

Weiner, Andrew M., OE

Wickenhagen, S., OV

Wolf, Richard, 02

Wolf, S., OG

Xue, Xiaoxiao, OE

Yang, Chi, $1 Y$

Yano, Tetsuji, $1 \mathrm{~F}$

Yao, Jianquan, 16, $1 \mathrm{G}$

Zappe, Hans, 02

Zhan, Qiwen, 11

Zhang, Haiwei, 16, $1 \mathrm{G}$ 


\title{
Conference Committee
}

\author{
Symposium Chairs
}

Reinhart Poprawe, Fraunhofer-Institut für Lasertechnik (Germany)

Koji Sugioka, RIKEN (Japan)

Symposium Co-Chairs

Guido Hennig, Daetwyler Graphics AG (Switzerland)

Yongfeng Lu, University of Nebraska-Lincoln (United States)

Program Track Chairs

Vladimir Ilchenko, OEwaves, Inc. (United States)

Paul O. Leisher, Rose-Hulman Institute of Technology (United States)

Conference Chairs

Alexis V. Kudryashov, Institute of Atmospheric Optics

(Russian Federation)

Alan H. Paxton, Air Force Research Laboratory (United States)

Vladimir S. Ilchenko, OEwaves, Inc. (United States)

Conference Co-Chair

Lutz Aschke, TRUMPF Lasertechnik GmbH (Germany)

Conference Program Committee

Andrea M. Armani, The University of Southern California

(United States)

Gaurav Bahl, University of Illinois at Urbana-Champaign

(United States)

Yanne K. Chembo, FEMTO-ST (France)

Jean-Claude M. Diels, The University of New Mexico (United States)

Hans Joachim Eichler, Technische Universität Berlin (Germany)

Andrew Forbes, University of the Witwatersrand (South Africa)

Pierre Galarneau, INO (Canada)

Thomas Graf, Universität Stuttgart (Germany)

Tobias J. Kippenberg, Ecole Polytechnique Fédérale de Lausanne

(Switzerland)

James R. Leger, University of Minnesota, Twin Cities (United States)

Andrey B. Matsko, OEwaves, Inc. (United States)

Gualtiero Nunzi Conti, Istituto di Fisica Applicata "Nello Carrara" (Italy) 
Andrew W. Poon, Hong Kong University of Science and Technology (Hong Kong, China)

Michelle L. Povinelli, The University of Southern California

(United States)

Michael J. Scaggs, Neoteric Concepts, LLC (United States)

Haiyin Sun, Chemlmage Corporation (United States)

Kunihiko Washio, Paradigm Laser Research Ltd. (Japan)

Yun-Feng Xiao, Peking University (China)

Lei Xu, Fudan University (China)

Lan Yang, Washington University in St. Lovis (United States)

\section{Session Chairs}

1 Microresonators: Novel Topologies and Devices I

Vladimir S. Ilchenko, OEwaves, Inc. (United States)

2 Microresonators in Lasers and RF Photonics

Yun-Feng Xiao, Peking University (China)

3 Frequency Combs with Optical Resonators I: Joint Session with Conferences 10088 and 10090

Konstantin L. Vodopyanov, CREOL, The College of Optics and Photonics, University of Central Florida (United States)

4 Frequency Combs with Optical Resonators II: Joint Session with Conferences 10088 and 10090

Andrea M. Armani, The University of Southern California (United States)

5 Microresonators: Novel Topologies and Devices II Yun-Feng Xiao, Peking University (China)

6 Microresonators: Nonlinear Effects, Optomechanics, and Sensing I Yanne K. Chembo, FEMTO-ST (France)

7 Beam Shaping I: Joint Session with Conferences 10090 and 10097 Stefaan Vandendriessche, Edmund Optics Inc. (United States)

8 Beam Shaping II: Joint Session with Conferences 10090 and 10097 Vladimir S. Ilchenko, OEwaves, Inc. (United States) Michael J. Scaggs, Haas Laser Technologies (United States)

9 Microresonators: Nonlinear Effects, Optomechanics, and Sensing II Andrey B. Matsko, OEwaves, Inc. (United States)

10 Microresonators: Nonlinear Effects, Optomechanics, and Sensing III Gualtiero Nunzi Conti, Istituto di Fisica Applicata "Nello Carrara" (Italy) 
11 Microresonators: Nonlinear Effects, Optomechanics, and Sensing IV Vladimir S. Ilchenko, OEwaves, Inc. (United States)

12 Control and Computer Simulation of Laser Modes

Alan H. Paxton, Air Force Research Laboratory (United States)

13 Beam Diagnostics and Shaping

Alexis V. Kudryashov, Institute of Atmospheric Optics (Russian Federation) 
Proc. of SPIE Vol. 10090 1009001-12

Downloaded From: https://www.spiedigitallibrary.org/conference-proceedings-of-spie on 26 Apr 2023
Terms of Use: https://www.spiedigitallibrary.org/terms-of-use 